\title{
Effects of wetting and compression/recovering time on the compressional behaviour of sanitary napkin layers
}

DOI: 10.35530/IT.072.04.1795

\author{
SUKRAN KARA
}

\begin{abstract}
REZUMAT
Effects of wetting and compression/recovering time on the compressional behaviour of sanitary napkin layers

Sanitary napkins are technical textile products which are used by women. They are designed as layered structures to fulfil several end-use properties at the same time. One of the most important properties of sanitary napkins is absorption property and this is widely studied in the literature. On the other hand, formability and sensorial comfort of sanitary napkins are of great importance but they are ignored during scientific researches. During daily life, women sit or sleep for certain time intervals and their sanitary napkins are exposed to compressional forces. If the sanitary napkin will squeeze and not recover, this can result with poor sensorial comfort and low formability. Also, wetting of sanitary napkins during usage can worsen the compressional properties. Therefore in this study, effect of wetting and compression/recovering time on the compressional behaviours of sanitary napkins was evaluated. Study was focused on separate sanitary napkin layers in order to detect the most problematic layers. Two compression times and four recovering times were applied to samples for compression tests. Also, sanitary napkin layers were characterised by scanning electron microscopy, unit mass, thickness and bending measurements. According to results, top sheet layer was the most compressible layer in dry and wet states. This is expected to give a soft and resilience sense to the sanitary napkin. Absorbent layer was responsible for low compressibility of sanitary napkins under different compression/recovering times. Bending rigidity of absorbent layer was the highest in dry state but it exhibited a dramatic decrement after wetting.
\end{abstract}

Keywords: sanitary napkin layers, dry compressibility, wet compressibility, thickness loss, compression-recovery time, bending behaviour

Influența umectării și timpului de comprimare/revenire asupra comportamentului la compresie al straturilor tampoanelor igienice

Tampoanele igienice sunt produse textile tehnice care sunt utilizate de către persoane de sex feminin. Acestea sunt concepute ca structuri stratificate pentru a îndeplini mai multe cerințe de utilizare finală în același timp. Una dintre cele mai importante proprietăți ale tampoanelor igienice este proprietatea de absorbție și aceasta este studiată pe larg în literatura de specialitate. Pe de altă parte, formabilitatea și confortul senzorial al tampoanelor igienice sunt de o mare importanță, dar sunt ignorate în timpul cercetărilor științifice. În viața de zi cu zi, femeile stau în poziție șezând sau dorm în anumite intervale de timp, iar tampoanele igienice pe care le poartă sunt expuse forțelor de compresie. Dacă tamponul igienic se va stoarce și nu își va reveni, acest lucru poate avea ca rezultat un confort senzorial scăzut și o formabilitate redusă. De asemenea, umezirea tampoanelor igienice în timpul utilizării poate agrava proprietățile de compresie. Prin urmare, în acest studiu, a fost evaluat efectul umectării și al timpului de comprimare/revenire asupra comportamentului la compresie al tampoanelor igienice. Studiul s-a axat pe straturi de tampoane igienice separate pentru a detecta cele mai problematice zone. Doi timpi de comprimare și patru timpi de revenire au fost aplicați probelor pentru testele de compresie. De asemenea, straturile tampoanelor igienice au fost caracterizate prin microscopie electronică de scanare, determinarea masei, grosimii și capacității de îndoire. Conform rezultatelor, stratul superior a fost cel mai compresibil strat în stare uscată și umedă. Se așteaptă ca acest lucru să ofere un tușeu moale și rezistență tamponului igienic. Stratul absorbant a fost responsabil pentru compresibilitatea scăzută a tampoanelor igienice în diferite perioade de comprimare/revenire. Rigiditatea la îndoire a stratului absorbant a fost cea mai ridicată în stare uscată, dar a prezentat o scădere dramatică după umectare.

Cuvinte-cheie: straturi ale tamponului igienic, compresibilitate uscată, compresibilitate umedă, pierderi de grosime, timp de revenire din compresie, comportament la îndoire

\section{INTRODUCTION}

Sanitary napkins are a member of absorbent/disposable hygiene products and they are used by women to collect the menstrual fluids hygienically. Sanitary napkins are layered materials to fulfil different enduse properties at the same time. In an ordinary sanitary napkin, there are 4 distinct layers. These layers include textile and film structures. The first layer is the porous top sheet film that is in contact with the body. Top sheet layer is designed to transfer the menstrual flow to the inner parts of the sanitary napkin, faster. Under the top sheet, acquisition-distribution layer (ADL) exists. ADL is responsible of taking the menstrual fluid from the top sheet and transfer it to the absorbent layer. Absorption layer takes the fluid 
and usually stores it in the gel form. The composition and structure of the absorbent layer may change. The last layer is the back sheet film. Back sheet has additional adhesive tapes for preventing shifting [1-3]. For ADL and absorbent layers, nonwoven structures are used as they are faster to produce, they can absorb high amounts of liquid and they are comfortable [4].

A sanitary napkin should exhibit many properties such as absorbability, leakage prevention, odour prevention, comfort, mobility, fit to the body contour and etc. In the literature, researches are usually focused on the absorption and moisture management properties of absorbent layer. For example; Karakurd Elma et al. investigated the effect of absorbent layer thickness and the ratio of superabsorbent polymer particles on the acquisition time and liquid acquisition capacities [5]. Wijesingha and Perera examined the usability of corn-husk fibres as the absorbent layer [6]. Das et al. produced absorbent layers with different concentrations of superabsorbent viscose fibres and tested their properties [7]. Similar research works can be found in the literature on sanitary napkins, incontinence pads or baby diapers [4, 8-14]. In addition, there are some survey and field studies in the literature, which question the sanitary napkin usage, perception, accessibility etc. in local places such as African countries and India [15-22]. As seen from the literature search, the studies on sanitary napkins are frequent on absorption properties. But in fact, some other properties such as bending rigidity and compressional behaviour of sanitary napkins are of great importance but they have been ignored during scientific researches.

During usage, sanitary napkins are subjected to compressive forces as a result of moving, sitting, sleeping and other daily actions. The compression and subsequent thickness recoveries of sanitary napkins are repeated during the day. This can lead to fragmentations in nonwoven content and cause shape changes during usage. As a result, the wearer can feel discomfort and experience leakage. Also, compression can change the porosity, hydraulic and absorption properties of nonwoven layers. This can also adversely affect the absorptive performance of sanitary napkins [23-26]. In addition, compressibility is related to softness and fullness of the textile structures [27]. So the compressional behaviour like compressibility and thickness recovery should be provided in order to maintain the hand and sensorial comfort properties of sanitary napkins.

Another ignored research field for sanitary napkins is flexibility, in other terms, bending behaviour. Sanitary napkins are fixed to underwear by means of adhesive layer and wings. Because of the layered and voluminous structure of the sanitary napkin, it can resist getting the shape and it can give discomfort to the user. A sanitary napkin serves with partially dry and partially wet parts during menstruation. It is known that textile structures may exhibit different properties in dry and wet conditions [28]. So the properties of dry and wet sanitary napkins should be tested, separately. In the context of this study, by considering the literature search, compressional properties and bending behaviour of sanitary napkin layers were investigated both in dry and wet states. To determine the time dependency, compressional behaviours were evaluated for 2 compression times and 4 recovering times. The research especially targeted the sanitary napkin layers to make comparisons between them and decide the main layer which affects the aforementioned mechanical properties of the end-product. It was aimed to close the lack about this subject in the literature.

\section{MATERIALS AND METHODS}

\section{Materials}

Materials of this study consisted of a commercial sanitary napkin and its separate 4 layers. The samples were supplied from a Turkish company (Kocaeli, Turkey). Properties of the layers and the sanitary napkin are given in table 1. Top sheet and back sheet layers were both polyethylene (PE) films but they were differed by the production technology. Other two layers, namely ADL and absorbent layers were nonwoven fabrics. They were composed of wood pulp and superabsorbent polymer (SAP).

\section{Methods}

\section{Microscopic evaluation}

Surface topographies of sanitary napkin layers were evaluated by using scanning electron microscope (SEM) (Jeol 6060). Energy of $5 \mathrm{kV}$ was applied during operation. Both front sides and back sides of sanitary napkin layers were observed with 30 times magnification. Also 75 and 200 magnification levels were used for measurements.

\begin{tabular}{|c|c|c|c|c|}
\hline \multicolumn{7}{|c|}{ MATERIALS OF THE STUDY } \\
\hline Material & Layer name & Sample code & Raw materials & Production technology \\
\hline 1st layer & Top sheet & TS & PE & Perforated film \\
\hline 2nd layer & ADL & ADL & Pulp & Airlaid nonwoven \\
\hline 3rd layer & Absorbent layer & ABL & Pulp+SAP & Airlaid nonwoven \\
\hline 4th layer & Back sheet & BS & PE & Film \\
\hline Sanitary napkin & Gathered & SN & - & - \\
\hline
\end{tabular}


Determination of unit mass and thickness

Unit mass of samples were determined according to TS EN 29073-1 standard by using an electronic balance [29]. Thickness of samples were determined according to TS 7128 EN ISO 5084 standard by using James Heal RxB Cloth Thickness Tester under $5 \mathrm{~g} / \mathrm{cm}^{2}$ thickness test pressure [30]. Thickness and unit mass measurements were repeated 5 times for each sample type.

All the tests were performed under standard atmosphere conditions $(65 \pm 4 \%$ relative humidity and $20 \pm 2^{\circ} \mathrm{C}$ ) after being conditioned for 24 hours.

Determination of thickness loss and compressibility Sanitary napkins are exposed to compression loads while sitting, sleeping, walking and working for different time intervals during the day. In this study, an experimental setup was built in order to simulate the compressional forces on the sanitary napkin. According to a study [31], where the pressure maps of 68 people (36 of them were women) were obtained while sitting on a wood seat model, the maximum pressure was detected as $0.1059 \mathrm{kgf} / \mathrm{cm}^{2}(105.9$ $\left.\mathrm{gf} / \mathrm{cm}^{2}\right)$ and it dropped to $0.053 \mathrm{kgf} / \mathrm{cm}^{2}\left(53 \mathrm{gf} / \mathrm{cm}^{2}\right)$ when sat to a pressure absorbing seat material. As the sanitary napkin partially faces the compression load during sitting, $50 \mathrm{gf} / \mathrm{cm}^{2}$ load was selected for simulating real life conditions.

Samples were placed on a wood platform and a static load of $50 \mathrm{gf} / \mathrm{cm}^{2}$ was applied on them. The duration of load application was selected as $2 \mathrm{~h}$ and $4 \mathrm{~h}$. After the stated time intervals, the load was removed and thickness of samples were measured under 5 and $50 \mathrm{~g} / \mathrm{cm}^{2}$ thickness test pressures after predetermined time intervals (immediately after load removal ( $0 \mathrm{~min}$.) and 2,5 and $10 \mathrm{~min}$. after load removal). Also thickness of samples was measured before loading. By using the measured thickness results, compressibility and thickness loss values of samples were calculated according to equations 1 and $2[32,33]$ :

$$
\text { Compressibility }=C=\frac{t_{5}-t_{50}}{t_{5}} \times 100
$$

where $t_{5}$ is thickness measured under $5 \mathrm{~g} / \mathrm{cm}^{2}$ thickness test pressure, $t_{50}$ - thickness measured under $50 \mathrm{~g} / \mathrm{cm}^{2}$ thickness test pressure.

$$
\text { Thickness loss }=t_{l}=\frac{t_{i}-t_{r}}{t_{i}} \times 100(\%)
$$

where $t_{i}$ is initial thickness (thickness before loading), $t_{r}$ - recovered thickness (thickness after 0, 2, 5 and 10 min. after load removal).

Compressibility values were calculated for all time intervals (before loading and 0, 2, 5 and $10 \mathrm{~min}$. after load removal). Also, thickness loss values were calculated for all time intervals and for $5 \mathrm{~g} / \mathrm{cm}^{2}$ and $50 \mathrm{~g} / \mathrm{cm}^{2}$ thickness test pressures. $t_{i}$ and $t_{r}$ values are schematized in figure 1.

\section{Determination of bending behaviour}

Bending rigidity of sanitary napkin and sanitary napkin layers were determined according to ASTM D

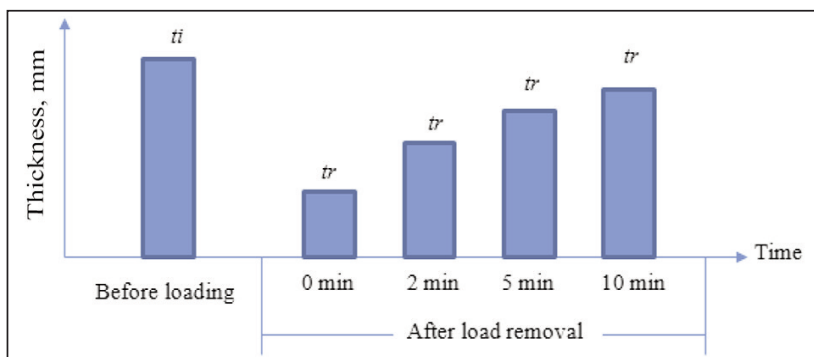

Fig. 1. Schematics of initial and recovered thickness values

1388-B standard (Heart Loop Method) [34]. Sample dimensions were $2.5 \mathrm{~cm} \times 25 \mathrm{~cm}$ and test dimensions were $2.5 \mathrm{~cm} \times 20 \mathrm{~cm}$. Bending rigidity of samples was determined in the machine direction by considering the shape of the sanitary napkin.

Measurements were performed for two sides of each sample and the average was taken. For each sample type, tests were repeated for 4 times according to the standard. The measured loop lengths were used to calculate the bending rigidity values, according to equation 3 . Bending length $(c), f_{2}(\theta)$ and $\theta$ were calculated according to equations 4,5 and 6 , respectively [35]:

$$
\text { Bending rigidity }=G=1.421 \cdot 10^{-5} \cdot w \cdot c^{3}(\mu \mathrm{joule} / \mathrm{m})
$$

$$
\begin{gathered}
c=0.1337 L \cdot f_{2}(\theta)(\mathrm{cm}) \\
f_{2}(\theta)=(\cos \theta / \tan \theta)^{1 / 3} \\
\theta=32.85 \cdot((I-0.1337 L) /(0.1337 L)) \quad\left(^{\circ}\right)
\end{gathered}
$$

where $L$ is strip length in $\mathrm{cm}, w$ - unit mass in $\mathrm{g} / \mathrm{m}^{2}$ and $I-$ loop length in $\mathrm{cm}$. Measurement of loop length in heart loop method is schematised in figure 2 .

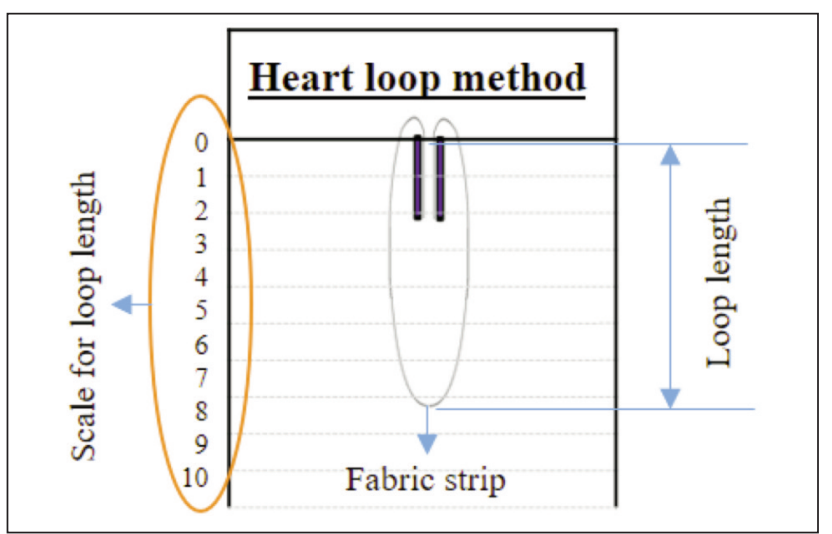

Fig. 2. Schematics of heart loop bending rigidity measurement

Wetting of samples for wet bending test and wet compression test

For the wet bending and wet compressibility tests, samples were wetted with synthetic urine $(0.9 \% \mathrm{NaCl}$ solution) $[5,10,36]$ which was kept at standard atmosphere conditions for $48 \mathrm{~h}$ before the tests.

For the wet bending test, samples with $2.5 \times 25 \mathrm{~cm}$ sizes were wetted with $10 \mathrm{ml}$ of synthetic urine with 
the help of pipette. To wet the samples equally along the long side, $1 \mathrm{ml}$ of synthetic urine was applied to every $2.5 \mathrm{~cm}$ length. The samples were kept in this situation for $5 \mathrm{~min}$ and then excessive solution was removed by putting the samples between two drying papers for 10-15 seconds. Before and after wetting, samples were weighed to calculate the average amount of absorbed solution.

Similarly, for wet compression test, $5 \times 5 \mathrm{~cm}$ samples were wetted with $4 \mathrm{ml}$ synthetic urine to keep the same ratio of wetting $\left(0.16 \mathrm{ml} / \mathrm{cm}^{2}\right)$ with the wet bending test. After removing the excessive solution, weighing and thickness measurements were performed as in aforementioned tests.

\section{RESULTS AND DISCUSSIONS}

\section{Microscopic evaluation}

SEM image of the sanitary napkin cross section is given in figure 3. Front and back side views of sanitary napkin layers are given in figure 4 . As seen from the figures, all the layers have different surface topographies and different structures. They are composed together to fulfil the requirements of a sanitary napkin.

According to SEM figures, top sheet had a voluminous perforated film structure. There were pores with $336.7 \mu$ diameter (10 measurements) and they formed protruding holes from back side to front side. This mesh structure both provides the fast liquid transfer to inner layers and soft surface. The ADL and SAP layers were in the form of nonwoven structures but they differed in the surface morphology. Face side of ADL was covered with fibrous structure with $38 \mu$ fibre thickness (10 measurements) and the backside had adhesive points with approximately $846 \mu$ width and $536 \mu$ height (4 measurements). Although having wood pulp again, surface topography of absorbent layer was

industuria textillă different than ADL layer. The superabsorbent polymer particles could be seen in absorbent layer. The average fibre thickness was calculated as $35 \mu$ by using 10 measurements. The back sheet was in the form of a solid film. This makes this layer waterproof. Some roughness of the back sheet surface could be

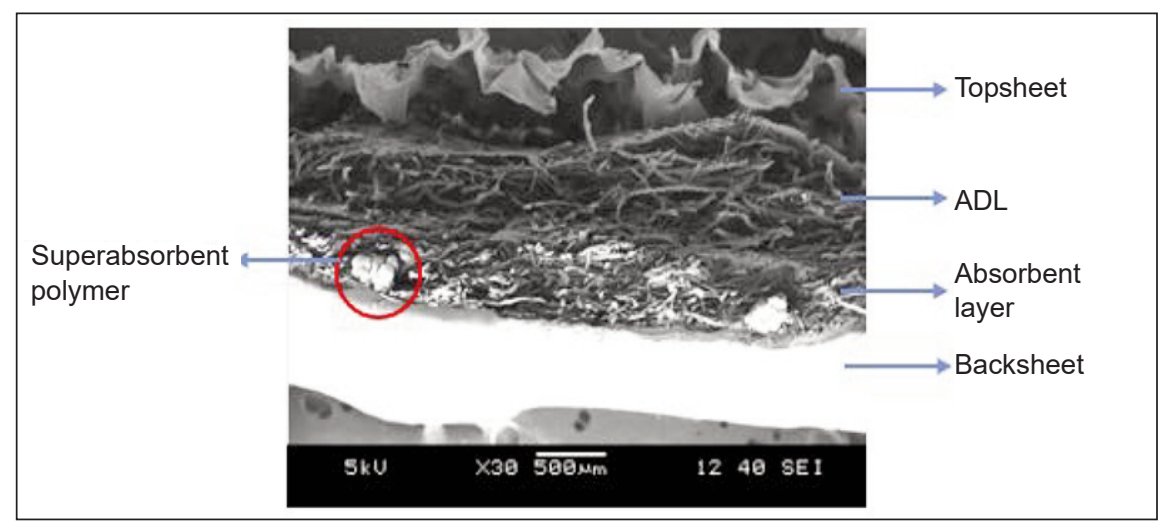

Fig. 3. Cross sectional view of the sanitary napkin

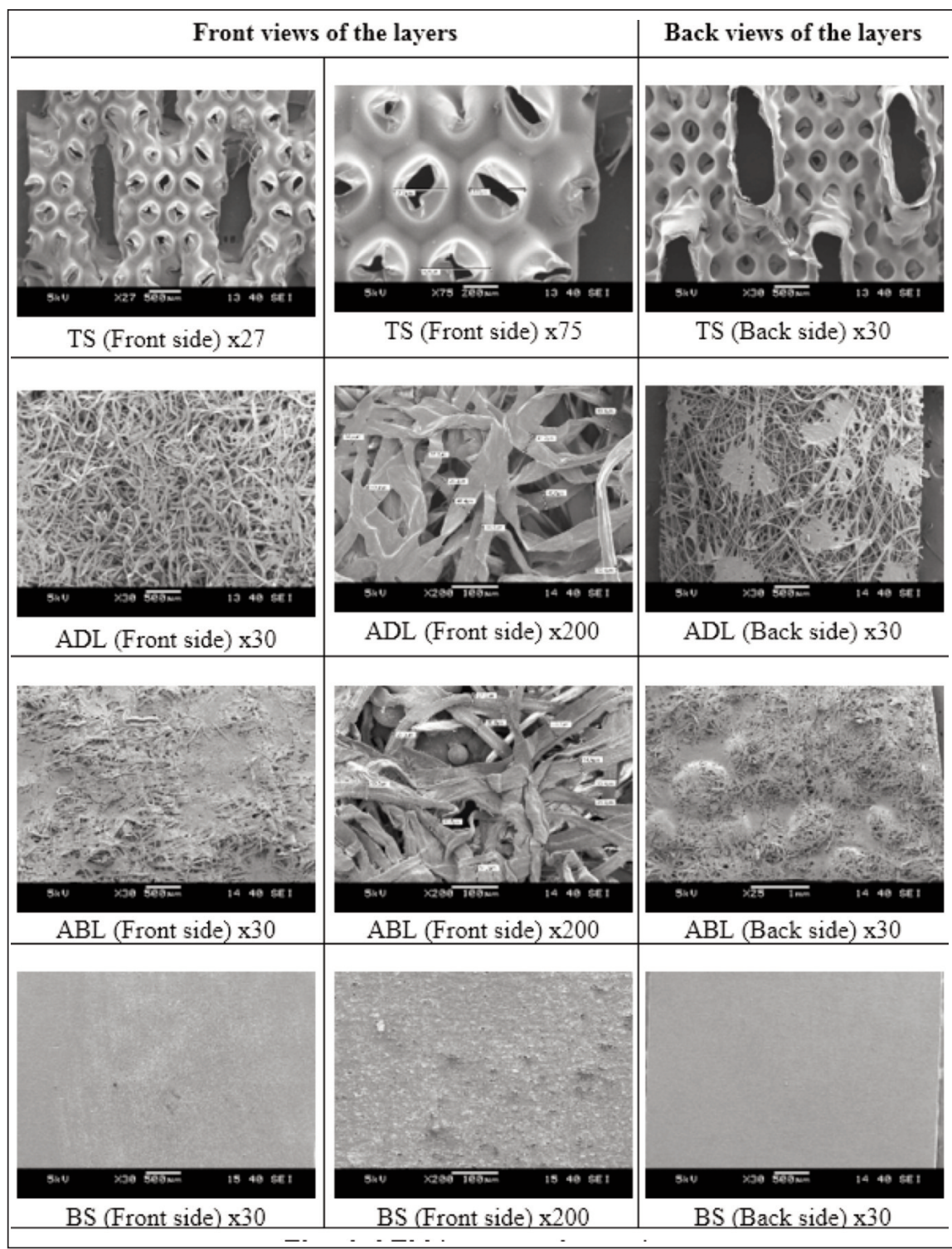

Fig. 4. SEM images of samples 


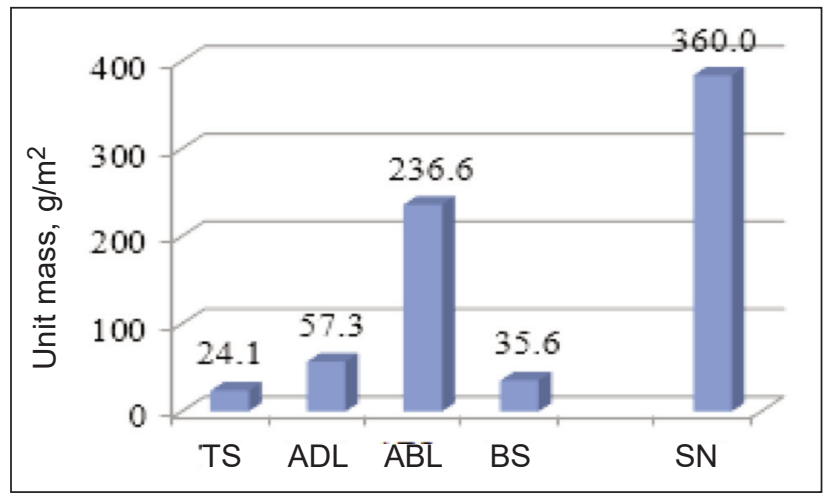

a

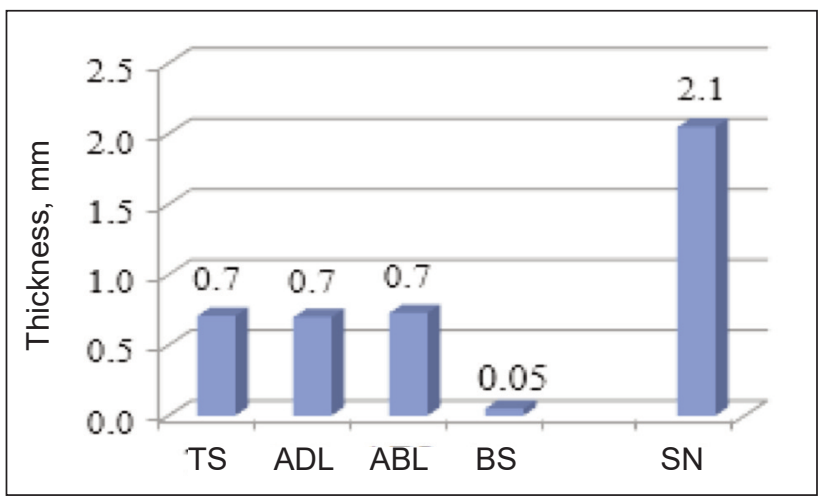

b

Fig. 5. Graghical representations of: $a$ - unit mass of samples; $b$ - thickness of samples

observed from front side view with 200 magnifications.

\section{Unit mass and thickness results of samples}

Unit mass and thickness results of samples are given in figure 5, $a$ and $b$, respectively. As seen in figure 5, $a$, unit mass of sanitary napkin layers varied in a wide range, from 24 to $236 \mathrm{~g} / \mathrm{m}^{2}$. The lightest layer of the sanitary napkin was top sheet. ADL and absorbent layer had heavier weights. But according to figure $5, b$, the thickness of top sheet, ADL and absorbent layer was the same as $0.7 \mathrm{~mm}$. This indicated compact structures for ADL and absorbent layer. Especially absorbent layer which included wood pulp and superabsorbent polymer had a very dense structure. Absorbent layer was 10 times heavier than top sheet. The back sheet layer was the thinnest layer and it was only $0.05 \mathrm{~mm}$ thick. But as back sheet was not in a perforated structure, it possessed a higher weight when compared to top sheet.

Sanitary napkin unit mass and thickness values were very high when compared to its separate layers. Sanitary napkin unit weight was about $360 \mathrm{~g} / \mathrm{m}^{2}$ which corresponded to total weight of layers. Sanitary napkin was a heavy weight textile structure and most of its weight was caused by absorbent layer. The thickness of sanitary napkin was $2.1 \mathrm{~mm}$ and again the total thickness of layers reflected to end-product thickness. With $2.1 \mathrm{~mm}$ thickness value, the sanitary napkin sample belonged to ultra-thin sanitary napkin class [1]. Unlike weight distribution of sanitary napkin layers; top sheet, ADL and absorbent layer had equal effects on the thickness of sanitary napkin.

\section{Amount of wetting}

For wet bending and wet compression tests, the samples were wetted according to aforementioned procedure. The mass increments of wet samples are given in figure 6 .

According to the figure, average mass increments of wet samples were similar for bending test and compression test. For top sheet and ADL layers, mass increments after wetting were around 200-240\%. Back sheet nearly did not absorb any amount of synthetic urine that is most probably about the dense

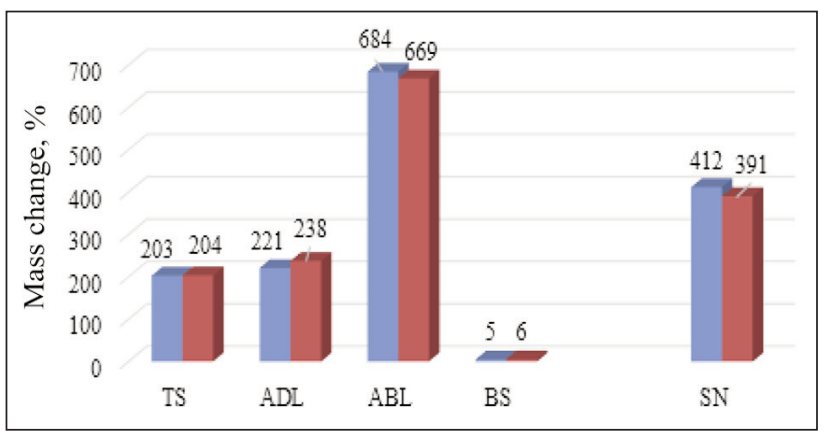

Fig. 6. Mass changes of samples: wet bending samples; $\mathbf{w}$ wet compressed samples

and hydrophobic structure of the film. Absorbent layer had the highest weight increments after wetting about $670-680 \%$. This is caused by the superabsorbent polymer content of this layer. For the sanitary napkin, weight changes were obtained around $400 \%$. The mass changes after wetting is related to absorption characteristics of sanitary napkin layers [37] which are the most for absorbent layer and least for back sheet.

\section{Compressibility behaviour of samples}

As compressional properties, thickness loss (\%) and compressibility (\%) of samples were determined after $2 \mathrm{~h}$ and $4 \mathrm{~h}$ static load application (compression). It was aimed to mimic the sitting action in the experimental design. Tests were repeated for dry and wet samples. Back sheet layer was not included in this test as it was very thin and the changes in thickness could not be detected by the measurement device. Compressibility values after $2 \mathrm{~h}$ and $4 \mathrm{~h}$ compression times are given in figure 7. According to figure, compressibility of top sheet was the highest for both dry and wet samples after $2 \mathrm{~h}$ and $4 \mathrm{~h}$ compression $(40-50 \%)$. This is related to voluminous structure of top sheet which was observed in SEM images in figure 4. Top sheet includes high amount of free air which makes it more porous and compressible. This porosity of top sheet makes fluids able to flow through the fabric [38]. Compressibility of top sheet was followed by ADL and absorbent layer, respectively. For all samples, compressibility was higher 


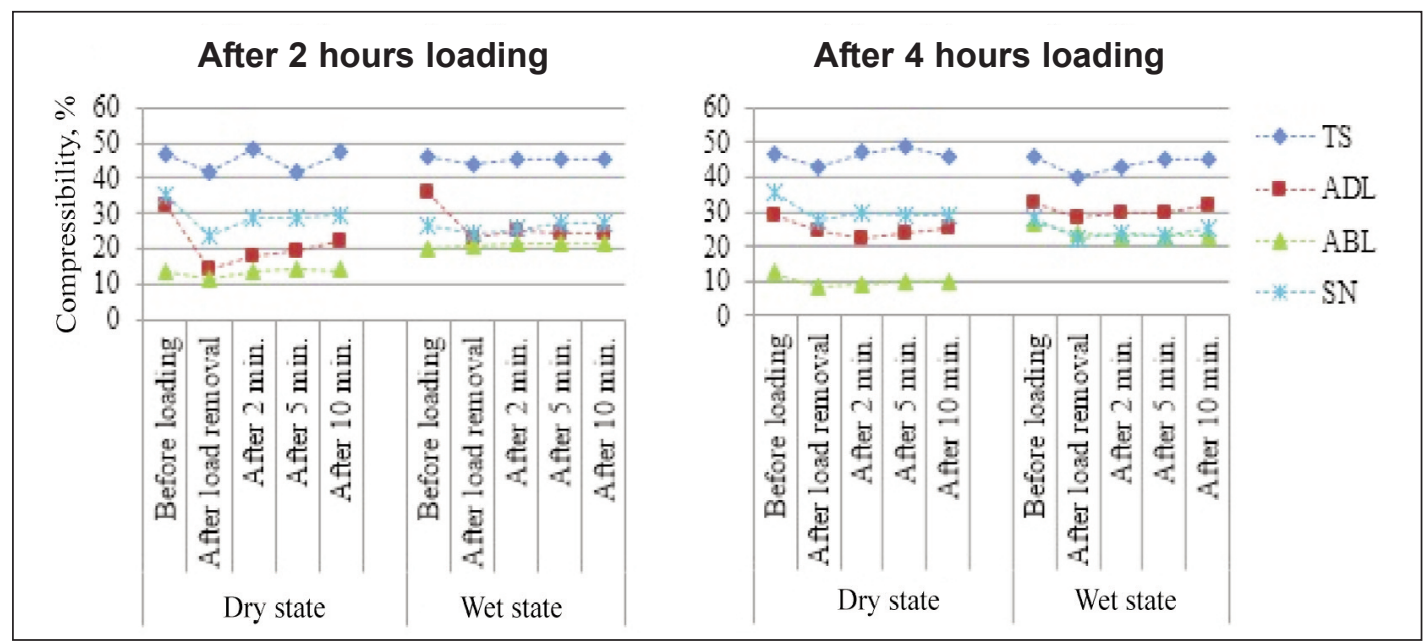

Fig. 7. Compressibility values after $2 \mathrm{~h}$ and $4 \mathrm{~h}$ compression

before static load application. After load removal, compressibility of samples started to increase by time and recovered mostly within 2 minutes.

Compressibility recoveries were more time dependent for dry samples. This is valid for both $2 \mathrm{~h}$ and $4 \mathrm{~h}$ compression times. For dry sanitary napkin, compressibility values were between top sheet and ADL layers for both $2 \mathrm{~h}$ and $4 \mathrm{~h}$ compression. After wetting, compressibility of sanitary napkin became closer to ADL or absorbent layer.

Thickness losses of samples after $2 \mathrm{~h}$ and $4 \mathrm{~h}$ compression times are given in figures 8 and 9 . Thickness losses of samples in dry state are similar for $2 \mathrm{~h}$ and $4 \mathrm{~h}$ loading for $5 \mathrm{~g} / \mathrm{cm}^{2}$ and $50 \mathrm{~g} / \mathrm{cm}^{2}$ test pressures. In dry states, maximum thickness losses were obtained generally from ADL layer whereas absorbent layer exhibited the least thickness losses. Thickness losses of top sheet and sanitary napkin were similar for dry and wet states. Thickness losses of absorbent layer increased after wetting.
Interestingly, ADL layer started to swell after 5 min of load removal for $4 \mathrm{~h}$ compression. It is a good property as ADL layer will stay open under load, maintain void volume, resist wet collapse, enhance the desorption properties of the fabric, preserve void volume capacity and maintain rapid fluid uptake after applications of fluid [28]. The thickness loss results measured at $5 \mathrm{~g} / \mathrm{cm}^{2}$ thickness test pressure were in accordance with thickness loss results measured at $50 \mathrm{~g} / \mathrm{cm}^{2}$ thickness test pressure.

In general, for all layers, thickness loss values decreased after 10 min of load removal for both dry and wet states (after $2 \mathrm{~h}$ and $4 \mathrm{~h}$ compression). This indicates that, after load removal, thickness of sanitary napkin will recover and sanitary napkin will continue to serve with a more voluminous structure. In a study, Debnath and Madhusoothanan found out that initial thickness and compressibility of the polyester needle-punched fabrics decreased but thickness loss increased under wet condition when compared to the dry condition [28]. It can be understood that these

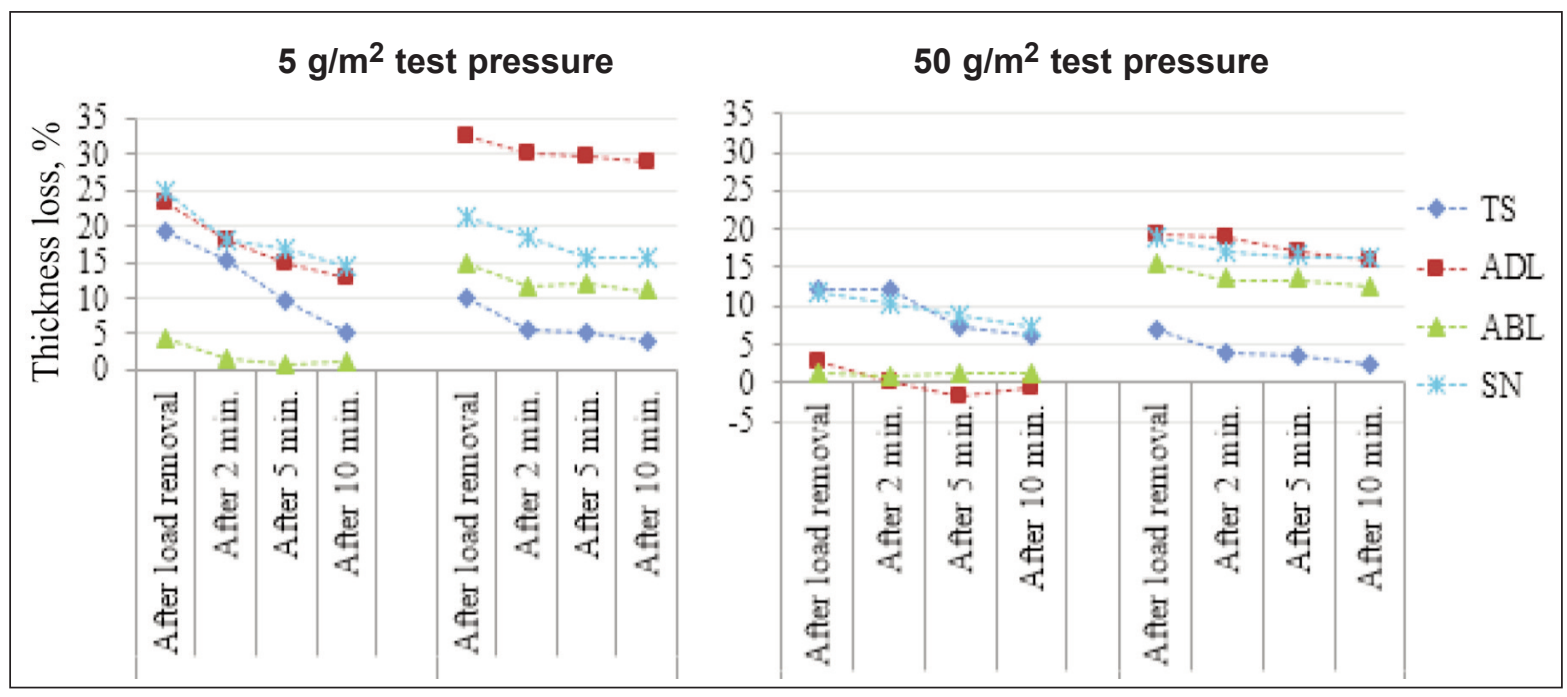

Fig. 8. Thickness loss values after 2 h compression 


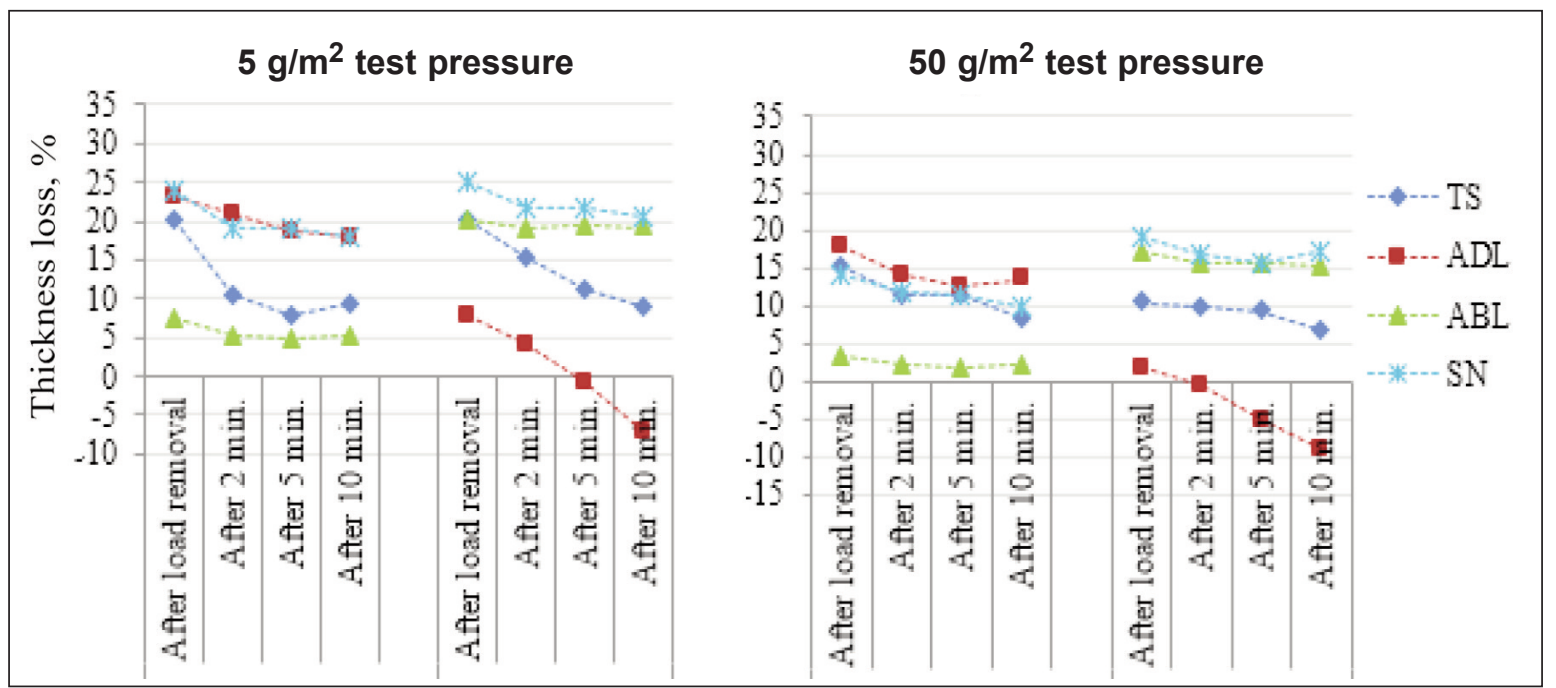

Fig. 9. Thickness loss values after $4 \mathrm{~h}$ compression

results do not fit with compressional behaviours of all sanitary napkin layers.

Although compressibility recoveries were mostly obtained after 2 min of load removal, samples exhibited some amounts of thickness losses even after 10 min of load removal.

\section{Bending behaviour of samples}

Bending results of samples are given in table 2. Also, average loop lengths measured during tests are schematized in figure 10. Bending lengths were calculated by using measured loop lengths.

Bending length results were between $1.46 \mathrm{~cm}$ and $3.41 \mathrm{~cm}$ before wetting and 1.02-2.04 cm after wetting. In general, bending lengths of sanitary napkin layers and sanitary napkin decreased after wetting and the loop lengths of samples increased after wetting.

Bending rigidity results are visualised in figure 11 . Before wetting, absorbent layer owned the highest

\begin{tabular}{|c|c|c|c|c|}
\hline \multicolumn{5}{|c|}{ BENDING RIGIDITY RESULTS } \\
\hline \multirow{3}{*}{ Code } & \multicolumn{2}{|c|}{ Dry bending properties } & \multicolumn{2}{c|}{ Wet bending properties } \\
\cline { 2 - 5 } & $\begin{array}{c}\text { Bending length } \\
(\mathbf{c m})\end{array}$ & $\begin{array}{c}\text { Bending rigidity } \\
(\boldsymbol{\mu} \mathbf{J} / \mathbf{m})\end{array}$ & $\begin{array}{c}\text { Bending length } \\
(\mathbf{c m})\end{array}$ & $\begin{array}{c}\text { Bending rigidity } \\
(\boldsymbol{\mu J} / \mathbf{m})\end{array}$ \\
\hline TS & 2.15 & 3.4 & 1.52 & 3.5 \\
\hline ADL & 2.80 & 17.5 & 1.30 & 5.7 \\
\hline ABL & 3.41 & 128.6 & 1.02 & 27.4 \\
\hline BS & 1.46 & 1.6 & 1.53 & 1.8 \\
\hline SN & 3.19 & 177.3 & 2.04 & 235.9 \\
\hline
\end{tabular}

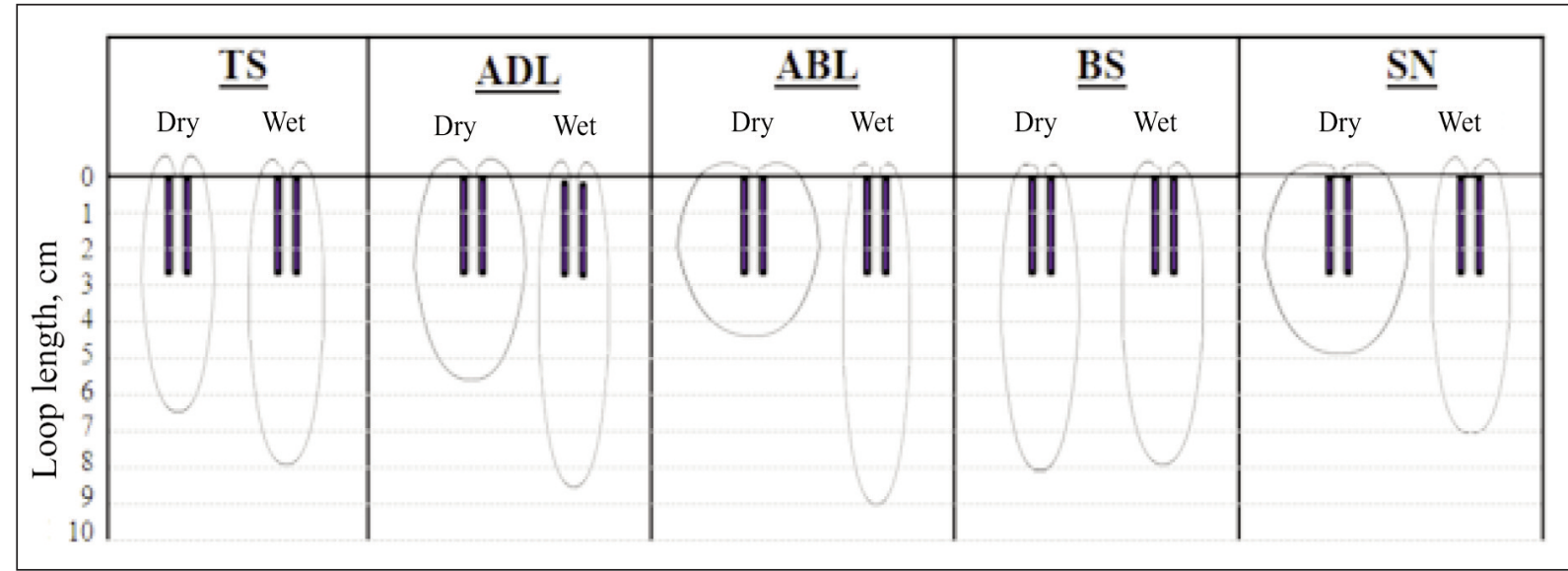

Fig. 10. Schematizing I (loop lengths) of samples in dry and wet states 
bending rigidity among the sanitary napkin layers. Also, the loop length was the lowest for this layer. The lightweight top sheet, $A D L$ and back sheet layers possessed ignorable bending rigidity results $(1.6-17.5$ $\mu \mathrm{J} / \mathrm{m}$ ) when compared to superabsorbent layer $(128.6 \mu \mathrm{J} / \mathrm{m})$ and sanitary napkin $(177.3 \mu \mathrm{J} / \mathrm{m})$, before wetting.

Bending rigidity values of top sheet and back sheet layers almost did not

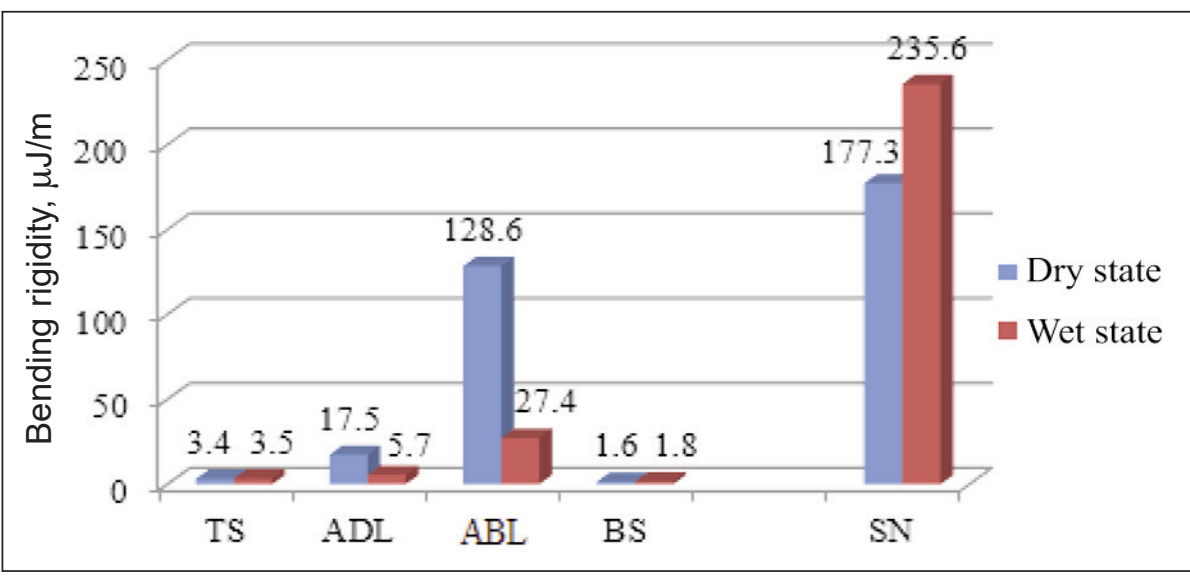

Fig. 11. Bending rigidity values of samples change after wetting. For

$A D L$ and absorbent layer, bending rigidity values decreased importantly after wetting. The increased weight of sanitary napkin layers resulted with longer loop lengths and smaller bending lengths (figure 10 and table 2). In contrary, sanitary napkin bending rigidity increased after wetting. The multilayer structure of the sanitary napkin restricted the loop length of the sanitary napkin. Its loop length only increased to $7.03 \mathrm{~cm}$ in spite of getting 4 times heavier after wetting. This situation resulted with higher bending rigidity for sanitary napkin after wetting procedure.

\section{CONCLUSIONS}

In this study, bending and compressional behaviours of sanitary napkin layers were determined in order to make comparisons between them and make inferences about the formability and sensorial comfort of sanitary napkins.

According to SEM evaluations, it was clearly observed that all 4 layers of the sanitary napkin were specially structured for their individual mission in the sanitary napkin. The layers differed in raw material, construction and surface morphologies. According to unit mass and thickness results, although top sheet, $\mathrm{ADL}$ and absorbent layer were equal in their thickness, their densities and compactness were very different. Top sheet was very light and porous and it made this layer more compressible even in dry and wet states. In contrary, absorbent layer was 10 times heavier than top sheet in spite of being in the same thickness. Altogether, the layers' unit mass and thickness results determined the overall weight and thickness of the sanitary napkin.

The bending and compressional behaviours of samples were determined both in dry and wet states as wet textiles can exhibit different properties under wet conditions. Same amount of synthetic urine was applied to sanitary napkin layers but they hold the amount according to their absorptive capacities [37]. According to bending test results, wetting did not importantly affect the bending rigidities of top sheet and back sheet layers. But especially, bending rigidity of absorbent layer decreased dramatically after wetting. This indicates to a more formable absorbent layer when it got wet because of menstrual flow. But as the unit mass of sanitary napkin increased too much and the layered structure restricted the loop length of sanitary napkin, bending rigidity of sanitary napkin did not decrease after wetting. This can lead to low formability and make the user feel discomfort. The compressional behaviour results showed that top sheet was the most compressible layer before and after being compressed with static load. So it can make the user feel a soft and dry surface. The compressibility of sanitary napkin was in somewhere around ADL and absorbent layer. The least compressible layer of the sanitary napkin was absorbent layer.

The thickness loss values after load application can be imagined as a sanitary napkins' compressional behaviour after a woman sits on it for $2 \mathrm{~h}$ and $4 \mathrm{~h}$. After the load removal, the thickness of sanitary napkin starts to recover. In this study, compressibility and thickness changes of the sanitary napkin layers were determined within $10 \mathrm{~min}$ after load removal. The thickness loss values determined at $5 \mathrm{~g} / \mathrm{cm}^{2}$ represented the free recovering of sanitary napkin after load removal. The thickness loss values determined at $50 \mathrm{~g} / \mathrm{cm}^{2}$ may be considered as the woman sit on the sanitary napkin again after load removal within $10 \mathrm{~min}$. So in this case, effect of repetitive sits on the sanitary napkin was tried to mimic. This setup of experiment was designed according to experiences and literature search but different setups may be made using different compression times or using dynamic loading cycles, in further studies.

As the back sheet material was only a few microns thick, the changes of back sheet could not be measured accurately by using the current test device. So the compressional behaviour results of back sheet were not added to the paper. In further studies, specially constructed gauges may be used to detect the thickness changes of back sheet. For this study, as the thickness changes of back sheet layer were very small when compared to other layers, back sheet layers compressional behaviours are omitted. 


\section{ACKNOWLEDGEMENTS}

Samples were supplied from a local sanitary napkin company. Author thanks for their kind support. A preliminary version of this study was presented in " $17^{\text {th }}$ National $3^{\text {rd }}$ International the Recent Progress Symposium on Textile Technology and Chemistry" with the caption "A comparative study on the permeability and sensorial comfort related mechanical properties of sanitary napkin layers" at November, 2019/Bursa/Turkey.

This current study was focused on compressional properties of sanitary napkin layers and the study is improved and differed by adding new parameters and measurements to the experimental design.

\section{REFERENCES}

[1] Wang, L., Sanitary napkins, Osada, Y., Kajiwara, K. (Eds.), Gels Handbook, USA: Academic Press, 2001

[2] Ajmeri, J.R., Ajmeri, C.J., Developments in the use of nonwovens for disposable hygiene products, Kellie, G. (Ed.), Advances in technical nonwovens, England: Woodhead Publishing, 2016

[3] Das, D., Composite nonwovens in absorbent hygiene products, Das, D., Pourdeyhimi, B. (Eds.) Composite nonwoven materials: Structure, properties and applications, England: Elsevier, 2014

[4] Pohlmann, M., Design and Materials Selection; analysis of similar sanitary pads for daily use, In: Int. J. Eng. Res. and Appl., 2016, 6, 11, 74-79

[5] Karakurd Elma, S., Kaynak, I., Nohut, S., Dasdemir, M., Development of novel sanitary napkin airlaid absorbent core material with improved liquid acquisition performance, In: 7th International Technical Textiles Congress, Izmir, Turkey, 10-12 October 2018

[6] Wijesingha, R.A.N.S., Perera, M.A.I., Developing sanitary napkins using corn husk fibres, In: Proceeding of the 15th Open University Research Sessions (OURS 2017), 2017, 129-132

[7] Das, A., Kothari, V.K., Makhija, S., Avyaya, K., Development of high-absorbent light-weight sanitary napkin, In: J. of Applied Polym. Sci., 2008, 107, 1466-1470

[8] Barman, A., Kathar, P.M., Development of eco-friendly herbal finished sanitary napkin, In: Int. J. Innovative Res. Sci. \& Technol, 2017, 4, 183-189

[9] Mishra, S., Pandey, R., Singh, M.K., Development of sanitary napkin by flax carding waste as absorbent core with herbal and antimicrobial efficiency, In: Int. J. Sci., Envir. \& Technol., 2016, 5, 404-411

[10] Yadav, S., Illa, M.P., Rastogi, T., Sharma, C.S., High absorbency cellulose acetate electrospun nanofibers for feminine hygiene application, In: Applied Mater. Today, 2016, 4, 62-70

[11] Dupuis, D., Rousse, D.R., Guidoin, R., King, M.W., A novel approach to measuring fluid flow in incontinence pads, In: Canadian Text. J., 1998, 115, 33-36

[12] Hong, K.H., Kim, S.C., Kang, T.J., Oh, K.W., Effect of abrasion and absorbed water on the handle of nonwovens for disposable diapers, In: Text. Res. J., 2005, 75, 7, 544-550

[13] Abou-Taleb, H.A., Design and development of reusable cloth diapers, In: Int. Res. J. Eng., 2013, 1, 1-18

[14] Yaman, N., Senol, M.F., Tayyar, A.E., Alternative test methods for assessing the mechanical properties of disposable diapers, In: Fibres and Text. in Eastern Europe, 2007, 15, 80

[15] Nyoni, A.B., Sibanda, P., Nkiwane, L.C., Gonde, P., Performance characteristics of local and imported sanitary pads Zimbabwe, In: J. of Sci. and Technol., 2014, Special Issue, 1-9

[16] Arugula, P., Paramasivam, S.K., Kanuri, N., Srirangam, A., Vemuluri, M., Perception on use of sanitary napkins among students in Khammam locality: A survey, In: Indian J. of Pharmacy Practice, 2017, 10, 133-136

[17] Hennegan, J., Dolan, C., Steinfield, L., Montgomery, P., A qualitative understanding of the effects of reusable sanitary pads and puberty education: Implications for future research and practice, In: Reproductive Health, 2017, 14,78

[18] Goyal, V., Scope and opportunities for menstrual health and hygiene products in India, In: Int. Res. J. Social Sci., 2016, 5, 18-21

[19] Baseline survey report on menstrual hygiene management, 2014, Available at: http://www.snv.org/public/cms/ sites/default/files/explore/download/girls_in_control_baseline_report_-_tanzania.pdf [Accessed on June 19, 2019]

[20] Market survey of menstrual hygiene items, 2015, Available at: https://www.elrha.org/wp-content/ uploads/2015/01/Final-Report-MHM-Market-Survey-Analysis.pdf [Accessed on June 19, 2019]

[21] Adika, V.O., Yabga, J., Apiyanteide, F., Ologidi, P., Ekpo, K.E., Perception and behaviour on use of sanitary pads during menstruation among adolescent school girls in Bayelsa State, Nigeria, In: Advances in Applied Sci. Res., 2011, 2, 6, 9-15

[22] Scott, L., Montgomery, P., Steinfield, L., Dolan, C., Dopson, S., Sanitary pad acceptability and sustainability study, 2013, Available at: https://www.doublexeconomy.com/wp-content/uploads/2010/09/7PageReport.pdf [Accessed on June 19, 2019]

[23] Nishio, S., Sanitary products and environmental problems, Osada, Y., Kajiwara, K. (Eds.), Gels Handbook, USA: Academic Press, 2001 
[24] Kothari, V.K., Das, A., Sarkar, A., Effect of processing parameters on properties of layered composite needlepunched nonwoven air filters, In: Ind. J. Fibre \& Text. Res., 2007, 32, 2, 196-201

[25] Kothari, V.K., Das, A., Studies on the compressional behaviour of nonwoven fabrics: Part I- Development of a constant rate deformation tester and its comparison with Essdiel thickness tester, In: Indian J. of Fibre and Text. Res., 1993, 18, 175-179

[26] Whitmore, D.L., Nonwovens containing immobilized superabsorbent polymer particles, In: International Nonwovens Journal, 2003, 3

[27] Taylor, P.M., Pollet, D.M., Static low-load lateral compression of fabrics, In: Text. Res. J., 2002, 2, 11, 983-990

[28] Debnath, S., Madhusoothanan M., Studies on compression properties of polyester needle-punched nonwoven fabrics under dry and wet conditions, In: J. of Ind. Text., 2012, 41, 4, 292-308

[29] TS EN 29073-1:1998. Textiles, test methods for nonwovens, part 1: Determination of mass per unit area, Ankara: Turk Standartları Enstitusu

[30] TS 7128 EN ISO 5084: 1998. Textiles-Determination of thickness of textiles and textile products, Ankara: Turk Standartları Enstitusu.

[31] Çetin, M.S., Tekstil Konfor Özellikleri Geliştirilmiş Ergonomik Büro Koltuğu Tasarımı, Ph.D Thesis Dokuz Eylul University, Izmir TURKEY, 2018

[32] Kara, S., Erdogan, U.H., Erdem, N., Effect of polypropylene fiber cross sectional shapes on some structural/mechanical fiber properties and compressibility behaviour of plain knitted fabrics, In: Fibers and Polym., 2012, 13, 6, 790-794

[33] Debnath, S., Madhusoothanan, M., Compression properties of polyester needlepunched fabric, In: J. of Eng. Fibers and Fabrics, 2009, 4, 4

[34] ASTM D1388. Standard test method for stiffness of fabrics. Option B, Heart loop test, West Conshohocken: ASTM International, 2018

[35] Hu, J., Structure and mechanics of woven fabrics, England: Woodhead Publishing, 2004

[36] Yokura, H., Niwa, M., Changes in disposable diaper properties caused by wetting, In: Text. Res. J., 2000, 70, 2, 135-142

[37] Gregorio, I., Zapata, F., Garcia-Ruiz, C., Analysis of human bodily fluids on superabsorbent pads by ATR-FTIR, In: Talanta, 2017, 162, 634-640

[38] Ghosh, S.K., Talukdar, M.K., De, P.K., Effect of number of passes on basic physical properties of nonwoven needlepunched fabrics, In: Indian J. of Fibre and Text. Res., 1994, 19, 61

\title{
Author:
}

\section{SUKRAN KARA}

Dokuz Eylul University, Engineering Faculty, Textile Engineering Department, Tınaztepe Campus, Buca, 35397, Izmir, Turkey

\section{Corresponding author:}

\author{
SUKRAN KARA
}

e-mail: sukran.kara@deu.edu.tr 